\title{
Media Concentration: A Critical Political Economy Perspective
}

\author{
Manfred Knoche \\ Paris-Lodron-University of Salzburg, Salzburg, Austria, manfred.knoche@plus.ac.at \\ http://www.medienoekonomie.at \\ https://kowi.uni-salzburg.at/ma/knoche-manfred/ \\ @Medoek \\ https://de.wikipedia.org/wiki/Manfred_Knoche
}

Translation from German: Christian Fuchs

\begin{abstract}
This article presents foundations of the analysis of media concentration from the perspective of the approach the critique of the political economy of the media and communication. It outlines the dangers and problems of media concentration, discusses the question of how to measure media concentration, identifies different types of media concentration, and gives a systematic overview of empirical studies of media concentration. As a result of the country comparison on a theoretical (macro) level with an analytically required high level of abstraction, first and foremost identities, commonalities and similarities with regard to the development of media concentration including its causes and consequences can be recognised. The author argues that media concentration also needs to be theorised. The paper distinguishes and discusses two such theoretical approaches: apologetic-normative competition theories of media concentration and critical-empirical theories of media concentration. Critical-empirical theories of media concentration situate media concentration in the context of the development of capitalism, which requires to use the critique of the political economy as theoretical foundation.
\end{abstract}

Keywords: media concentration, critique of the political economy of the media and communication, transformation, international comparison

\section{Acknowledgement:}

Manfred Knoche. 2013. Medienkonzentration. In Mediensysteme im internationalen Vergleich, hrsg. von Barbara Thomaß, 135-160. Konstanz: UVK. Zweite überarbeitete Auflage.

Translated into English and publication of the translation with permission by UVK.

\section{Preface: Manfred Knoche's Critique of the Political Econ- omy of the Media and Communication}

\section{Christian Fuchs}

Without Manfred Knoche, there would be no critique of the political economy of the media and communication in the German-speaking world. Comparable to the work of Graham Murdock and Peter Golding in the Anglo-Saxon world, Knoche, who was born on 24 September 1941 and recently celebrated his $80^{\text {th }}$ birthday, has conducted pioneering work that helped laying foundations of the approach of the critique of the political economy of the media. He made an important contribution to the development of media and communication studies and its sub-discipline of media economics. 
I have held Manfred Knoche in high esteem as an academic colleague since a time together at the University of Salzburg, where he held the Chair of Journalism and Communication Studies with a special focus on media economics from 1994 to 2009. Manfred Knoche began his studies and academic career in 1967 at the University of Mainz. The time of the student movement left a lasting political and academic mark on him. He says: "I consider it my personal good fortune that I was able to become part of the student movement", whose spirit of optimism and social criticism "shaped my thinking, but also my attitude to life". In 1973, he moved to the Free University of Berlin, where he successfully completed his master's degree in the same year, his doctorate in 1978 and his habilitation in 1981. In general, he says: "The Berlin period was very formative for me. Master's degree, doctorate, habilitation, assistant, assistant professorship, everything was at the Berlin Institute" for Journalism (Institut für Publizistik). From 1983 to 1994, he was professor of communication studies at the Vrije Universiteit Brussel.

Manfred Knoche stands for the development of an analysis of media and communication in capitalism that is empirically based and grounded in critical social theory, especially the critique of political economy. On this basis, he has covered a wide range of important topics: the capitalisation and restructuring of the media industry; media concentration research; non-commercial open access, decapitalisation of scholarly publishing as a critique of the political economy of scholarly communication; ideology; advertising; the nexus of state, capital and media; media technologies and digitalisation; media content analysis; non-commercial alternative media; the long-term analysis of the representation of the Greens in the daily press; electronic mass media in Europe; the youth press; the local press; the postal newspaper service; the coverage of strikes in the media industry; etc.

Manfred Knoche's work shows how significant critical theory and social criticism are for media and communication studies and how the capitalist social formation shapes, distorts and damages our everyday life and everyday communication. Characteristic of Manfred Knoche's work are, on the one hand, empirically based studies and, on the other, fundamental theoretical analyses of communication and the media in capitalist society. His work on the critique of the political economy of communication and the media is of great importance today for the critical analysis of the dynamics and contradictions of digital capitalism.

I wish Manfred Knoche many more years of creative critical work and thus possibilities and opportunities to continue to contribute to the development of the field of the critique of the political economy of the media and communication together with companions and young academics.

\section{Translations of Manfred Knoche's works published in tripleC:}

Manfred Knoche. 2021. Media Concentration. tripleC: Communication, Capitalism \& Critique 19 (2): 371-391. DOI: https://doi.org/10.31269/triplec.v19i2.1298

Manfred Knoche. 2021. Capitalisation of the Media Industry From a Political Economy Perspective. tripleC: Communication, Capitalism \& Critique 19 (2): 325-342. DOI: https://doi.org/10.31269/triplec.v19i2.1283 
Manfred Knoche. 2020. Science Communication and Open Access: The Critique of the Political Economy of Capitalist Academic Publishers as Ideology Critique. tripleC: Communication, Capitalism \& Critique 18 (2): 508-534. DOI: https://doi.org/10.31269/triplec.v18i2.1183

Manfred Knoche. 2019. The Crisis-Ridden Capitalist Mode of Production as Driving Force for Restructurations and Transformations in and of the Media Industry: Explanatory Theoretical Elements of a Critique of the Political Economy of the Media. tripleC: Communication, Capitalism \& Critique 17 (2): 287-307. DOI: https://doi.org/10.31269/triplec.v17i2.1137

Manfred Knoche. 2016. The Media Industry's Structural Transformation in Capitalism and the Role of the State: Media Economics in the Age of Digital Communications. tripleC: Communication, Capitalism \& Critique 14 (1): 18-47. DOI: https://doi.org/10.31269/triplec.v14i1.730

\section{Media Concentration: A Critical Political Economy Perspective}

\section{Manfred Knoche}

\section{Theoretical-Methodological Foundations of the International Comparison of Media Concentration}

Since global media concentration, like concentration in the economy as a whole, is a defining feature of capitalist economic formations and capitalist formations of society, it is appropriate to undertake an international comparison of media concentration on the basis of a critical political economy approach. A suitable starting point is Karl Marx's fundamental analysis of the connection between accumulation, concentration and centralisation of capital as an essential feature of capitalism (Marx 1867; Altvater, Hecker, Heinrich and Schaper-Rinkel 1999; Heinrich 2005).

The concentration analyses carried out on the basis of these theoretical-methodological foundations have the advantage of analytical explanatory and predictive power (Baran and Sweezy 1966; Bischoff et al. 2000; Huffschmid 1969, 2000; Kisker 1999; 2000; Mandel 1978; Sweezy 1970). Even established competition theorists sometimes recognise - albeit without consequences for their own theory development - "how realistically KARL MARX (capital letters in the original, MK) saw the capitalist competition process as a process of selection, displacement and concentration in the context of society as a whole. [...] from the point of view of competition theory, his analysis of the competitive process and the restrictions of competition is very significant, but has remained largely unnoticed by bourgeois economics" (Olten 1998, 41).

International comparisons of media concentration are therefore made in this article in the context of approaches to a critical political economy of media and communication (Fuchs and Mosco 2012; Herman and Chomsky 2002; Holzer 1994; McChesney 2000, 2008; McChesney, Wood and Foster 1998; Meier 1996/1997, 2003; Mosco 2009; Murdock and Golding 1973; Wasko, Murdock and Sousa 2011; Winseck and Jin 2011). The basis of the international comparison of the development of media concentration is a theory of concentration that is critical of capitalism (Knoche 2005a, b) within the framework of a critique of the political economy of the media (Knoche 2001, 2002, 2005c; Fuchs 2009). Since the comparison thus refers to a uniform type of capitalist societies, the method of agreement is primarily used, following John Stuart Mill's classic distinction between the method of difference and the method of agreement (BergSchlosser and Müller-Rommel 1992; Esser and Hanitzsch 2012; Kleinsteuber 2003; 
Melischek, Seethaler and Wilke 2008; Thomaß and Kleinsteuber 2011) ${ }^{1}$. As a result of the country comparison on a theoretical (macro) level with an analytically required high level of abstraction, first and foremost identities, commonalities and similarities with regard to the development of media concentration including its causes and consequences can be recognised. Differences, discordances and dissimilarities can at best be observed at a lower level of abstraction, at the empirical (micro) level, with regard to the degrees of concentration currently achieved and the temporal course of the media concentration processes.

\section{Relevance: Journalistic Diversity, Problems of Power and Legitimacy, Democ- racy}

The problem of media concentration is generally of relevance for society because it calls into question the democratic foundations of capitalist economic and social systems in practical and legitimising terms. In the media sector, this "systemic question" arises in two ways beyond the rest of the economy: economically with regard to the private economy, market and competition, which are also propagated as ideal control mechanisms for the media sector, and politically with regard to the ideals of media freedom and journalistic diversity as prerequisites for a democratic public sphere. The problem of concentration is generally, not only in the media sector (Jin 2008), of high political relevance, especially since the market and competition have been enforced as the sole means of controlling the economy and society in the course of worldwide neoliberal privatisation policies. Due to the real concentration processes, "the basis of legitimacy of the entire system is disappearing" (Huffschmid 1969, 67), as these concentration processes recognisably stand in considerable contradiction to the still widespread theories of competition and the state competition policy oriented towards them.

Note 1:

Concentration processes endanger the democratic foundations of capitalist economic and societal systems because they actually contradict the propagated ideals of competition and journalistic diversity.

In this respect, the concentration problem is also of considerable academic relevance, since concentration is promoted instead of controlled on the basis of neoliberal policy concepts (Knoche 1996b, 1997). At the same time, regularly adapted economic theories of competition shift the legitimacy framework in such a way that the degree of concentration achieved in the economy is legitimised (Olten 1998, Rittner and Kulka 2008, Schmidt 2012, Sjurts 2005). Competition theory thus fulfils an apologetic-ideological function of legitimising or concealing the concentration of economic-political rule and power by "abolishing competition without also abolishing the theory of competition" (Huffschmid 1969, 67).

Finally, the connection between media concentration and economic, journalistic and political power is relevant (Chomsky 2004; Knoche 1997; Leidinger 2003; McChesney and Nichols 2004; Meier 2007; Trappel, Meier, Schrape and Wölk 2002; Murdock

\footnotetext{
${ }^{1}$ Von Beyme $(2000,154 \mathrm{f})$ also sees the dominance of a "capitalist world system" and an increasing "uniformisation of the world", the consequences of which for the comparative method "cannot yet be fully assessed". From this, however, he concludes with a reference to postmodern thinking "as the finisher and not the overcomer of modernity", which has "placed the primacy of the difference method above the search for similarities": "Precisely because the world is converging, the difference method can be applied all the more radically for the remaining differences".
} 
1990; Prokop 2005). The journalistic power resulting from the economic power of the media companies, or more precisely the (capital) owners of these companies, refers to journalists and programme makers who have the power to enforce of information, opinion, legitimation and ideology that conform to the interests of those in power. The resulting political power extends to citizens, organisations, parties and the state. This concentration of power is of considerable social relevance because the autonomous power of the media owners to dispose of and shape the media, which is secured by property rights and additionally by guarantees of freedom of the press under the Basic Law, is essentially uncontrollable and fundamentally irreversible.

\section{Questions and Systematisation of Media Concentration's Measurement}

Questions for the international comparison of media concentration can be oriented towards a theoretical systematisation of the object of investigation (Knoche 1978, 1996a, 1997), which should be the basis for measurements and presentations of the development and status of media concentration in the different countries on a descriptive level. First of all, it is a matter of the fundamental question of what is regarded or evaluated as concentration at all. This question needs clarification not only from an academic point of view, but also from a socio-political and economic point of view, especially in connection with state regulation or concentration control.

Based on the systematisation of market-related concentration measurement (figure 1), a distinction must be drawn between different media sectors (press, radio, television, film, etc.) as concentration sectors. The differentiation according to concentration levels - international, national, regional, local - is important. In order to arrive at meaningful concentration analyses, a delimitation according to relevant markets is necessary within each of these concentration sectors and levels, which is carried out factually according to homogeneous product types, spatially according to distribution areas and temporally according to modes of publication/broadcast times. Since these distinctions are rarely made in the available country descriptions of media concentration, there is usually a systematic underestimation of the degrees of concentration. 


\section{Measurement of Media Concentration}

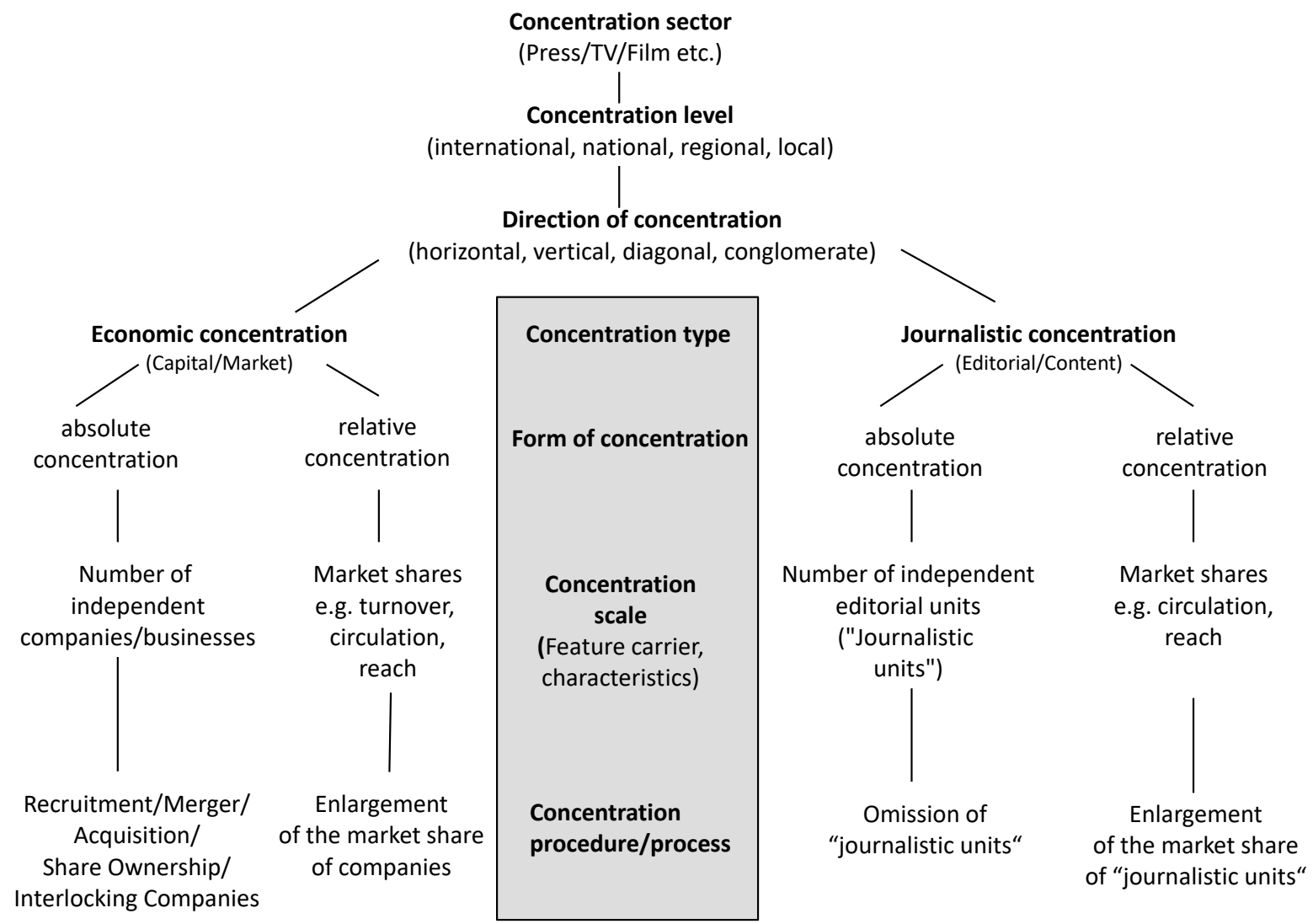

Figure 1 (own representation)

The regularity of national and international media concentration processes is differentiated according to four directions of concentration - horizontal, vertical, (media) diagonal and conglomerate - each according to media sectors (press, television, film etc.) and relevant markets. In this context, we find a process of market and capital concentration across all media sectors, which manifests itself primarily in the development of press groups into multi-media and communication corporations. Following common economic terminology, a distinction according to the following directions of concentration is relevant (Knoche 1996a: 109):

- horizontal concentration designates concentration phenomena at the same production level within an economic sector, an industry, a media sector or a relevant market;

- vertical concentration designates concentration phenomena at successive production levels such as procurement, production, and distribution;

- (media) diagonal concentration designates cross-media sector concentration phenomena such as interconnections between media sectors

- conglomerates mean cross-sectoral concentration phenomena such as interconnections between the media industry and other industries.

For measuring media concentration in media and communication studies, the distinction between two interrelated types of concentration, economic and journalistic concentration, is of fundamental importance. Economic concentration is usually measured in two ways: on the one hand as market concentration, on the other hand as capital 
concentration, which are, however, strongly interrelated. In competition theory - in analogy to Marx's concepts of the accumulation and centralisation of capital - a distinction is made between internal and external corporate concentration. Journalistic concentration is usually only formally represented as editorial concentration, rarely as concentration of information and opinions that are homogeneous in content.

Note 2:

Concentration in the media sector includes economic concentration, which appears as market concentration and as capital concentration, as well as journalistic concentration, which refers to the concentration of editorial units as well as to the homogenisation of content.

In this context, it is important to analyse to what extent economic concentration is the cause, trigger or precondition of journalistic concentration. Research should also be directed towards investigating to what extent there is journalistic concentration on a considerable scale in the face of a possibly low degree of economic concentration, in the form of homogeneous ideology production for the legitimisation and stabilisation of the capitalist formation of society.

Within these two types of concentration, a distinction must be made between two forms of concentration, absolute and relative concentration. In each case, the yardsticks of concentration are different economic or journalistic characteristics (independent companies, businesses, editorial units, "journalistic units") as well as economic or journalistic characteristics (e.g. turnover, circulation, reach). The usual limitation to the representation of absolute concentration, i.e. to the number of independent economic or journalistic units and possibly their reduction over time, is not very meaningful in relation to the representation of relative concentration based on the unequal distribution (disparity) of economic or journalistic features among the feature carriers within media sectors or relevant media markets.

\section{Problems and Perspectives}

The usual measurements are related to the states of concentration (degrees of concentration) reached at certain points in time. From the point of view of the development of concentration processes, however, various concentration processes are also of interest, such as capital holdings, interlocking relationships, mergers, takeovers/acquisitions, joint ventures; the formation of cartels, corporations, trusts and holding companies; strategic alliances, increases in market shares, etc. The consideration of concentration processes implies an analytical diagnosis of concentration phenomena (going beyond descriptive data documentation) as well as their explanation and prognosis as a cause-and-effect-impact analysis (Leidinger 2003; McChesney 2000; Siegert, Meier and Trappel 2010; Trappel, Meier, Schrape and Wölk 2002; fundamental for analysis of the entire economy is e.g. Working Group Alternative Economic Policy 1988).

Within the framework of a critical-empirical theory of media concentration, the cause-effect relationship shown in figure 2 is assumed (Knoche 2005a). Private ownership of the means of production as well as the application of the principles of profit maximisation and rivalry can be regarded as fundamental structural economic causes, immanent to the capitalist mode of production, of the concentration activities of media companies. In addition, deregulation and concentration promotion policies, which are pursued by the state and the media industry in a wide-ranging convergence of interests, also act as causes on the part of politics. Politically, it is not competition that is 
promoted (contrary to the official proclamations of competition policy models), but the international competitiveness of capital-rich media companies. In reality, this policy promotes national concentration and, in turn, international concentration (Huffschmid 1992, Knoche 2004). The relevant consequences from the point of view of democratic public sphere of the state-sponsored, at least not prevented worldwide concentration activities of media companies are visible in a variety of areas (figure 2, right hand side).

\section{Causes and Consequences of Media Corporations" Concentration Activities (Concentration Theory) \\ Causes \\ Concentration \\ Consequences}

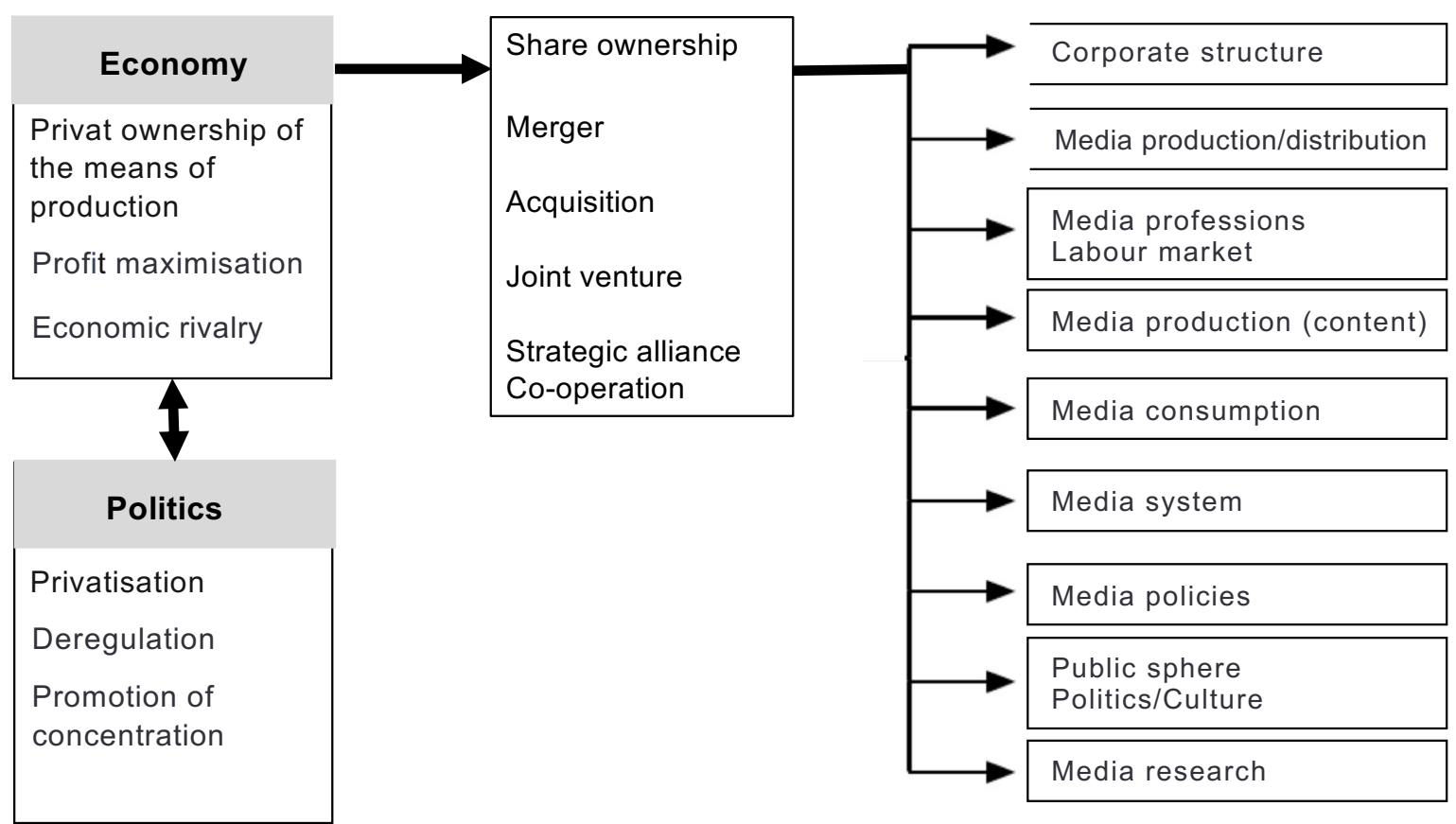

Figure 2 (Source: Knoche 2005a, 128)

The problems and perspectives of the international comparison of media concentration are thus not only determined by the problems and perspectives of media concentration research, but also by the explosive question of competition policy, concentration control and the regulation of the media industry. It is recognisable throughout the world that media concentration - in the same way as concentration in the entire economy is increasingly facilitated or promoted by deregulation or re-regulation, especially in the USA, which often serves as a model for re-regulation in European countries. On the basis of an empirical comparison of countries (Germany, France, Great Britain, Italy, USA) on the antitrust regulations and their legal application for mergers in the area of the press (merger control), "a remarkable identity with regard to the legal regulations and the decision-making practices" (Knoche and Zerdick 2002, 185) can be found.

Note 3:

Media concentration is increasingly facilitated or encouraged by deregulation or reregulation to a large extent because the international competitiveness of capitalrich media companies is sought. 
Control of media concentration is practised as symbolic politics, as non-decision politics (Farda 2000) or as "undermining media diversity" through "inaction" (Doyle 2007), as has been demonstrated by the years of (partly deliberate) inconclusive discussions of the European Parliament, the European Union, and the Council of Europe. An important means of symbolic politics are also the continuous changes in the guiding principles of competition theory and policy (Gabler Verlag 2012) in the direction of legitimising the real development of concentration, in stark contrast to the predefined intention of promoting competition (Knoche 2004). Consequently, extensive and versatile corporate concentration strategies are propagated and legitimised as necessary in the interest of the concentration-active companies (Sjurts 2005).

\section{Empirical Studies of Media Concentration}

Existing publications on (empirical) primary or secondary data investigations and studies of media concentration in different countries, which usually focus on peculiarities of individual countries and consequently on differences between countries, can be characterised according to how concentration-specific and directly/indirectly internationally comparative they are designed. A scale of five types of publications can be distinguished (ordered in ascending order of quality for international comparison on media concentration):

- Publications focused on the collection of additive single-country studies of national media systems or media markets in general, mostly not systematically strictly oriented to a uniform category system, from which, as a rule, more or less information on media concentration can also be derived on the basis of secondary data (Hans Bredow Institute 2009, Thomaß and Tzankoff 2001, Wilke 1992/1994/1996; using a uniform category system: Schneider and Schütz 2004, Stürzebecher 2004).

- Publications focused specifically on individual countries' media concentration, which were only carried out and published for one country, but can be used as a primary or secondary data source for independent international comparative studies if corresponding/similar studies have been published for other countries (e.g. Bagdikian 2004; Bonfadelli, Meier and Trappel 2006; Compaine and Gomery 2000; Doyle 2002; McChesney and Nichols 2004; Seethaler and Melischek 2006; Röper 2012; Vogel 2012).

- Publications focusing on the largest transnational media corporations in the world or in Europe or on global media companies, partly differentiated by media sectors, which allow partial indirect country comparisons dedicated specifically to media concentration (Hachmeister and Rager 2005, Herman and McChesney 1997, Kleinsteuber and Thomaß 2004).

- Publications focused on the collection of additive, but on a uniform category system oriented single country studies, which allow indirect country comparisons dedicated specifically to media concentration (European Federation of Journalists 2004, 2005; Media Diversity Institute/International Federation of Journalists/Internews Europe 2009; Nordicom 2009; on the regulation of media concentration: Knoche and Zerdick 2002; Kommission zur Ermittlung der Konzentration im Medienbereich (KEK) 2007, 2010; Schulz, Held and Arnold 2007).

- Publications with direct country comparisons according to a uniform category system dedicated specifically to media concentration (Sánchez-Tabernero and Carvajal 2002, Ettl-Huber 2008). 
Furthermore, the available publications can be differentiated according to the geographical area to which $^{2}$ they refer:

- Studies focused on only one country each in Western Europe/the European Union (Bonfadelli, Meier and Trappel 2006; Doyle 2002; Der Beauftragte der Bundesregierung für Kultur und Medien 2008; Hans Bredow Institute 2008; Kommission zur Ermittlung der Konzentration im Medienbereich (KEK) 2010; Ofcom 2012; Seethaler and Melischek 2006; Röper 2012; Vogel 2012; on concentration control in Germany: Schulz and Held 2006; Schulz, Dreyer and Hagemeier 2011).

- Studies focused on selected countries in Western Europe/the European Union (Council of Europe 2004, 2009; European Commission 2007, 2008/2009; European Parliament 2008; Thomaß and Kleinsteuber 2011; Kommission zur Ermittlung der Konzentration im Medienbereich (KEK) 2007; Nordicom 2009; Trappel, Meier, d'Haenens, Steemers and Thomaß 2011, Sánchez-Tabernero and Carvajal 2002)

- Studies focused on selected countries in Eastern Europe (European Federation of Journalists 2004, Ettl-Huber 2008, Thomaß and Tzankoff 2001)

- Studies focused on selected countries in Western and Eastern Europe (Doyle 2006, European Federation of Journalists 2005, Schneider and Schütz 2004)

- Studies focused on the USA (Bagdikian 2004, Baker 2007, Compaine and Gomery 2000, Federal Communications Commission (FCC) 2010, McChesney and Nichols 2004, Noam 2009)

- Studies focused on selected countries in Europe/the USA (Knoche and Zerdick 2002; Schulz, Held and Arnold 2007)

- Studies focused on selected countries worldwide: USA, Central America, South America, Europe, Africa and the Middle East, (East) Asia and Australia (Hachmeister and Rager 2005, Hans Bredow Institute 2009, Herman and McChesney 1997, Kleinsteuber and Thomaß 2004, Wilke 1992/1994/1996).

Based on the research practised so far, the common approaches to concentration research can be roughly divided into two groups depending on the fields of concentration dealt with (Knoche 1978, 1996a; Kopper 1995):

- Studies of market structures as indicators of market concentration: market shares of media companies in diverse relevant markets in diverse media sectors (press, television radio, film etc.) at different levels of concentration (international, national, regional, local) according to different types of concentration (economic, journalistic); these studies correspond to the approaches of competition theory and competition policy and want to determine the degree of concentration on the basis of market power and market dominance.

- Studies of ownership structures (media ownership, cross-media ownership) as indicators of capital concentration and corporate concentration: capital shares of media owners in diverse media sectors as well as across sectors.

For an analytically sound characterisation of the development of concentration, both approaches have to be applied in a complementary way. However, studies of market

\footnotetext{
${ }^{2}$ As not all publications on all continents and countries could be processed for this article due to time and space constraints, the following list is only exemplary with a clear focus on Germany, Europe, and the USA.
} 
concentration are dominant. These are inadequate and distract from the problem insofar as they ignore the real cross-market concentration of capital as the overriding market power and power of disposal.

\section{Summary of Findings}

As Seethaler (2004) also emphasises in his literature report on Vergleichende Ansätze in der Erforschung der europäischen Pressemärkte ("Comparative Approaches in the Study of European Press Markets"), there is a lack of studies that meet the methodological-systematic demands of comparative research. Complaints about a missing or inadequate data basis are justified on the one hand, but on the other hand they often have an alibi character in order to conceal the unwillingness to take political action in the form of regulation and concentration control. An illustrative example of this is the rudimentary self-critical remark by Jens Cavallin, the long-standing chairman of the Committee of Experts on Media Pluralism and Transparency of Media Ownership at the Council of Europe: "from one point of view there is a wealth of information available, even an embarras de richesse [italics in original]. From another perspective, however, our ignorance is desperate. [...] The Council of Europe has a wealth of documentation, as assembled for the most part in internal working documents" (Cavallin 1995, 14).

Strictly data-oriented media concentration research proves to be a kind of Sisyphean task, which has been aptly characterised as follows: "The difficulty consists above all in the fact that the share and ownership formations, especially in the case of large media companies, are often extremely convoluted and change many times, the documentalist [sic!] must consequently constantly aim at flying objects, so to speak" (Luyken 199, 621). For the mostly only gradual differences in the development of concentration in the various countries or the minor shifts within the rankings in a time comparison are hardly relevant in relation to the commonality/sameness that in each of these countries and across countries internationally, i.e. worldwide, there are multinational and multimedia global media corporations that are intertwined in the same way. This is reflected in almost all international comparative publications. Referring to research results of the Council of Europe (2004), for example, it is stated: "the majority of European countries are characterised by high and increasing levels of media and crossmedia concentration [...] similar content is being recycled across different channels in different territories" (Doyle 2006, 122). This sameness of the status of concentration is expressed above all in the domination of these large national and transnational media corporations with a multitude of shareholdings and business areas in a large number of countries. However, the concentration problem is by no means limited to the " 50 largest media corporations in the world" (Hachmeister and Rager 2005), but also includes a multitude of regional and local media monopolies in all countries.

\section{Note 4:}

Media concentration can be observed internationally as a continuous process in every country and across countries, whereby differences in the extent of concentration between countries take a back seat to the fundamental commonality and identity of this process.

This empirically proven realisation of a fundamental (structural and procedural) identity of the development of media concentration as well as its causes and consequences in all capitalist countries is the adequate basis for a critical theory of media concentration and critical political action based on it. It is a central finding of international comparative 
media concentration research that in the course of the regular concentration processes immanent to capitalism, more and more capital and power of disposal is concentrated worldwide, cumulatively, almost exponentially growing, in the hands of a few media owners.

It is therefore a very abbreviated approach if - as is usually the case - the problem of media concentration is limited to the description of phenomena of market and corporate concentration. On the one hand, this systematically underestimates the extent of concentration because, for example, the significance of cross-market and crosscompany concentration is lost from view or, for example, the diversification of media objects of a media corporation is even wrongly evaluated as a reduction of concentration. In answering the question "Who Owns the Media Companies?" (Compaine/Gomery 2000), it is less a question of knowing the names of media owners as "media moguls". Rather, it should be noted that media companies worldwide are in principle (with the exception of some public service media organisations) "owned" by a few individual owners of capital ${ }^{3}$.

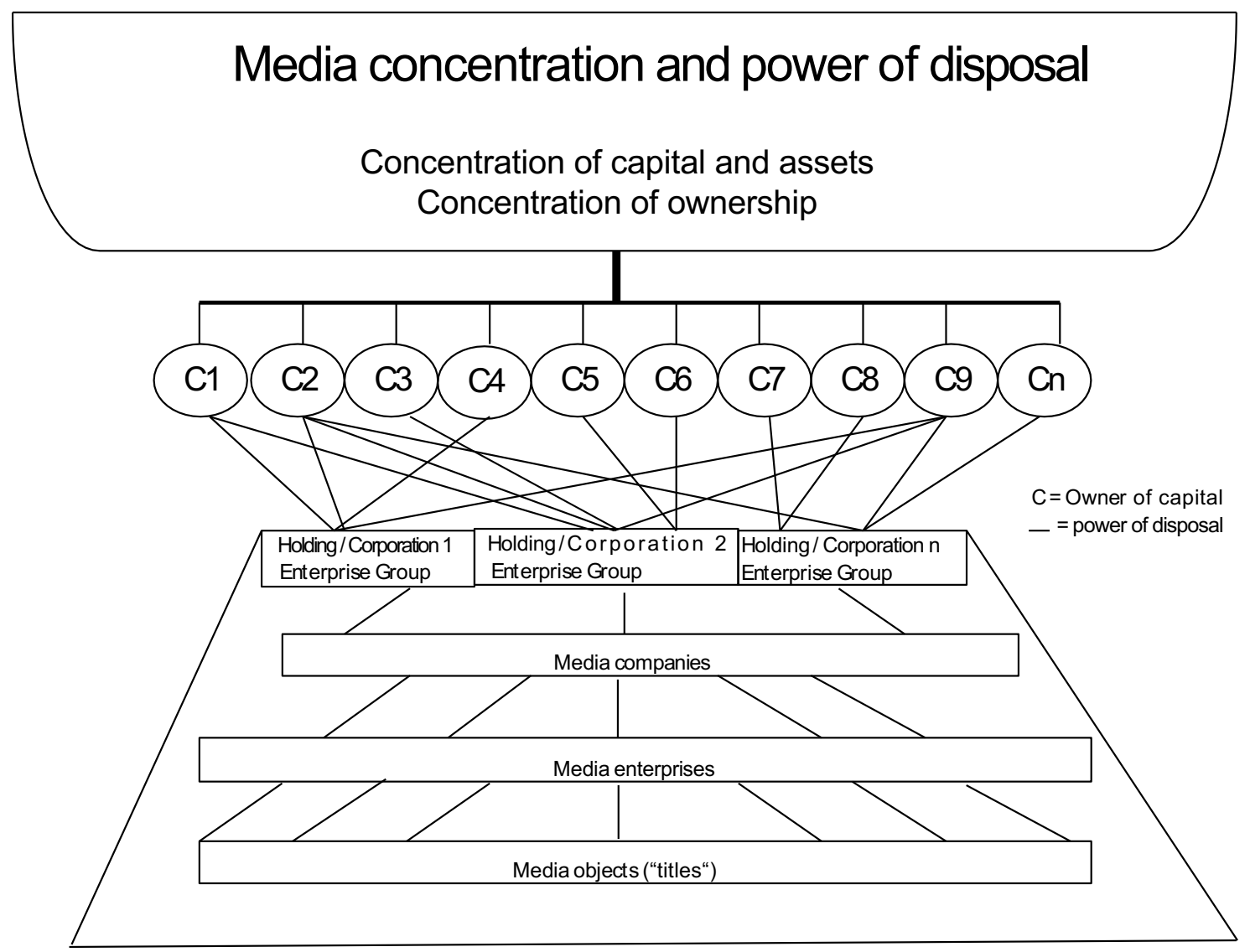

Figure 3 (own representation)

Thus, as shown schematically in figure 3, media concentration is a matter of a concentration of individual ownership of the means of production of media corporations, com-

\footnotetext{
${ }^{3}$ The fact that individual capital owners join together to form companies does not change the basic fact that individual capital owners are the owners of the media companies (in contrast to public or social ownership, for example in the form of public service organisations). The legitimacy of individual owners to dispose of media production is based - very much in contradiction to democracy - only on their appropriated capital, which was created by their wage earners.
} 
panies and enterprises as well as the derived individual power of disposal that is secured by law, i.e. a form of relatively unrestricted rule by the owners of capital. At the same time, this implies an unrestricted power of disposal over the content of media products and thus over the shaping of the social, political and cultural public sphere. The latter is by no means only a problem of journalistic diversity, but it is a fundamental problem for democracies that in capitalist societies media production is also under the power of disposal of those individual capital owners and their interest in capital accumulation, whereby there is a concentration of large amounts of capital, assets and property (Keiser 1931).

As meritorious as the in part extremely elaborate single-country studies with data describing media concentration may be, they are of relatively little value academically and politically, insofar as they do not contribute to the academic explanation and forecasting of concentration phenomena and processes in a theoretical and socio-political context. Therefore, we require the "development of a critical-empirical media concentration theory in communication studies, which takes the place of the apologetic-normative economic theories of competition" (Knoche 2005a, 124). The basis for such a theory is the regular process of the concentration of capital, means of production and command over labour, identical with accumulation, analysed and predicted by Marx in connection the analysis of centralisation as "concentration of capitals already formed, destruction of their individual independence, expropriation of capitalist by capitalist, transformation of many small into few large capitals" (Marx 1867, 77).

\section{Competition Theory Versus Concentration Theory}

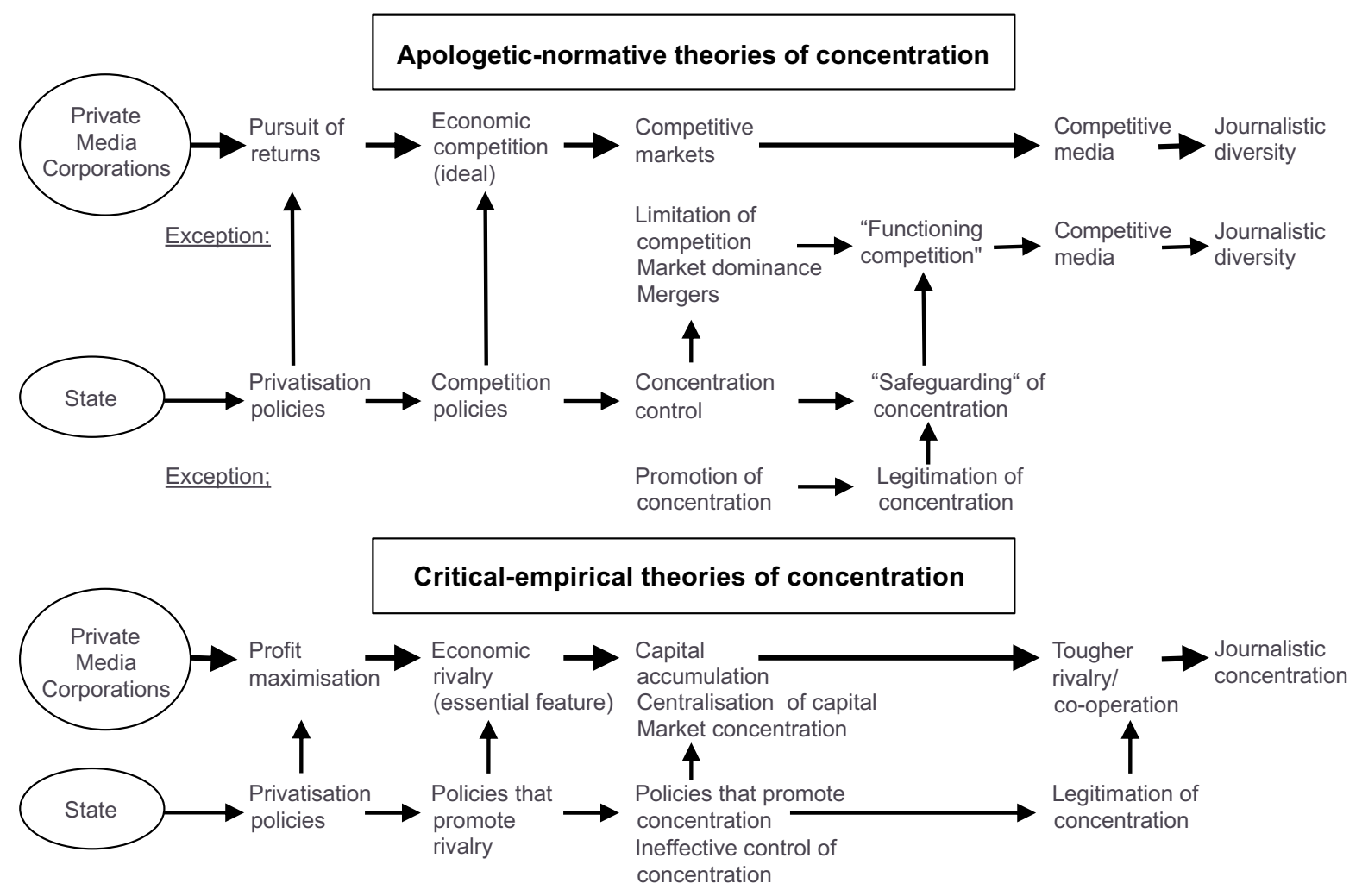

Figure 4 (Source: Knoche 2005a, 125) 
In the critical-empirical concentration theory, the actual economic rivalry of individual capital owners associated with profit maximisation is seen as a systematic, regular cause of concentration processes that have negative consequences for the freedom of information, the freedom of opinion and the diversity of the media (figure 4, lower part). This is diametrically opposed to the prevailing theories of competition (figure 4, upper part), which are characterised as apologetic-normative because, by propagating competition as a normative target function, they focus on a model with allegedly positive consequences for the freedom of information, the freedom of opinion and the diversity of the media. Concentration is seen here only as an exception that can (allegedly) be "controlled" or propagated as positive "functioning competition". Apologeticnormative theories fulfil the function of distracting from the empirically proven actual causes of media concentration and its negative consequences. Another essential contrast between the two opposing theoretical approaches lies in the definition of the function of the state. In theories of competition, the state is normatively propagated as a "protector" of competition and a "controller" of concentration, whereas in the critical concentration theory, the state is analysed - on the basis of empirical data - as an actual promotor and legitimiser of concentration.

\section{Note 5:}

The critical-empirical theory of concentration sees the actual economic rivalry of individual capital owners associated with profit maximisation as a systematic, regular cause of concentration processes that have negative consequences for the freedom of information and opinion as well as the diversity of the media.

In summary, it can be stated that media concentration is a problem area that has been dealt with comparatively much in international comparisons in academic studies and political action. But nevertheless,

"communication studies has mostly shown itself to be a bearer of misgivings about concentration processes in the media market. It likes to point to the important role of the press and diversity for the formation of opinion and will in society. This, however, remains a cheap lip service" (Holtz-Bacha 2006, 289).

The same "action-reaction scheme" (Knoche 1996, 103ff) can be seen worldwide: (State) commissions react to concentration processes actively driven by media companies by awarding research contracts for data documentation (Federal Communications Commission (FCC) 2010, Media Diversity Institute/International Federation of Journalists/Internews Europe 2009, Ofcom [Office of Communications UK] 2012). At the EU level, media concentration is reinterpreted with clearly ideological (distracting, obfuscating) intent by changing the words that are used (European Commission/Task Force for Co-ordination of Media Affairs 2012; Karppinen 2006, 2010). The talk is of media pluralism, freedom and diversity. Instead of control, regulation or government intervention, transpareny, observation, monitoring and corporate governance are recommended. As Neelie Kroes, Vice-President of the European Commission responsible for the Digital Agenda, programmatically proclaims, the focus is on "Safeguarding Media Pluralism in the EU" (Kroes 2012). To this end, a High-Level Group on Media Freedom and Pluralism and a Centre for Media Pluralism and Media Freedom (https://cmpf.eui.eu/) were established in 2011. This form of symbolic politics has been rightly criticised: 
"The analysis of contemporary policy debates indicates that the notion of media pluralism has been too readily reduced to an empty catchphrase or conflated with consumer choice and market competition. In this narrow technocratic logic, pluralism is often unreflectively associated with quantitative data in a way that leaves unexamined key questions about social and political values, democracy, and citizenship" (Karppinen 2010, 3).

\section{References}

Altvater, Elmar, Rolf Hecker, Michael Heinrich, and Petra Schaper-Rinkel. 1999. Kapital.doc: Das Kapital (Vol. 1) by Marx in Schaubildern mit Kommentaren. Münster: Westfälisches Dampfboot.

Arbeitsgruppe Alternative Wirtschaftspolitik. 1988. Wirtschaftsmacht in der Marktwirtschaft. Zur ökonomischen Konzentration in der Bundesrepublik. Cologne: Pahl-Rugenstein.

Bagdikian, Ben H. 2004. The New Media Monopoly: A Completely Revised and Updated Edition with Seven New Chapters. Boston, MA: Beacon Press.

Baker, C. Edwin. 2007. Media Concentration and Democracy: Why Ownership Matters. Cambridge:Cambridge University Press..

Baran, Paul A. and Paul M. Sweezy. 1966. Monopoly Capital. An Essay on the American Economic and Social Order. New York: Monthly Review Press.

Berg-Schlosser, Dirk and Ferdinand Müller-Rommel. 1992. Entwicklung und Stellenwert der Vergleichenden Politikwissenschaft. In Vergleichende Politikwissenschaft. Ein einführendes Studienbuch, edited by Dirk Berg-Schlosser and Ferdinand Müller-Rommel, 1125. Opladen: Leske und Budruch.

Beyme, Klaus von. 2000. Die politischen Theorien der Gegenwart. Eine Einführung. Wiesbaden: Westdeutscher Verlag. $8^{\text {th }}$ edition.

Bischoff, Joachim, Paul Boccara, Karl Georg Zinn et al. 2000. Die Fusions-Welle. Die Großkapitale und ihre ökonomische Macht. Hamburg: VSA.

Bonfadelli, Heinz, Werner A. Meier, and Josef Trappel, eds. 2006. Medienkonzentration Schweiz. Formen, Folgen, Regulierung. Bern: Haupt Verlag.

Cavallin, Jens. 1995. Comparative Studies on Media Concentration in Europe. In Media Structure and the State. Concepts, Issues Measures, edited by Karl Erik Gustafsson, 934. Gothenburg: Gothenburg University.

Chomsky, Noam. 2004. Eine Anatomie der Macht. Der Chomsky-Reader. Hamburg/Nienna: Europa Verlag.

Compaine, Benjamin M. and Douglas Gomery. 2000. Who Owns the Media? Competition and Concentration in the Mass Media Industry. London: Erlbaum. Third edition.

Council of Europe. 2009. Methodology for Monitoring Media Concentration and Media Content Diversity. Report Prepared by the Group of Specialists on Media Diversity (MC-SMD). Strasbourg: Council of Europe. https://rm.coe.int/CoERMPublicCommonSearchServices/DisplayDCTMContent?documentld=0900001680483b18

Council of Europe. 2004. Transnational Media Concentrations in Europe. Report prepared by the Advisory Panel to the CDMM on Media Concentrations, Pluralism and Diversity Questions. APMD (2004) 7. Strasbourg: Council of Europe.

Der Beauftragte der Bundesregierung für Kultur und Medien, ed. 2008. Medien- und Kommunikationsbericht der Bundesregierung 2008. Berlin. http://www.bundesregierung.de/Content/DE/ Anlagen/BKM/2009-01-12-medienbericht-teil1-barrierefrei.pdf? blob=publicationFile\&v $=2$

Doyle, Gillian. 2007. Undermining Media Diversity: Inaction on Media Concentration and Pluralism in the EU. In Media and Cultural Policy in the European Union, edited by Katherine Sarikakis, 135-156. Amsterdam/New York: Brill.

Doyle, Gillian. 2006. Structure and Development of Media Ownership in Europe. In Media Economics in Europe, edited by Jürgen Heinrich and Gerd G. Kopper, 121-137. Berlin: Vistas. 
Doyle, Gillian. 2002. Media Ownership. The Economics and Politics of Convergence and Concentration in the UK and European Media. London: Sage.

Esser, Frank and Thomas Hanitzsch, eds. 2012. The Handbook of Comparative Communication Research. New York: Routledge.

Ettl-Huber, Silvia. 2008. Konzentration von Einflusspotenzialen in Mediennetzwerken: Eine netzwerkanalytische Untersuchung von Eigentumsverflechtungen in den neuen EUStaaten Mittel- und Osteuropas. Münster: Lit.

European Commission. 2008/2009. Independent Study on Indicators for Media Pluralism in the Member States - Towards a Risk-Based Approach. Prepared for the European Commission Directorate-General Information Society and Media (SMART 007A 2007-0002) by K. U.Leuven - ICRI (lead contractor), Jönköping International Business School MMTC, Central European University - CMCS, Ernst \& Young Consultancy Belgium. The country Reports, Final Report and Annex I: User Guide. Leuven. https://ec.europa.eu/information society/media taskforce/doc/pluralism/pfr report.pdf

European Commission. 2007. Media Pluralism in the Member States of the European Union Commission Staff Working Document. \{SEC(2007) 32\}. Brussels.

http://ec.europa.eu/information society/media taskforce/doc/pluralism/media pluralism swp en.pdf

European Commission/Task Force for Co-ordination of Media Affairs. 2012. Freedom and Pluralism of the Media. The Need for Transparency, Freedom and Diversity in Europe's Media Landscape. https://ec.europa.eu/commission/presscorner/detail/en/IP $07 \quad 52$

European Federation of Journalists. 2005. Media Power in Europe: The Big Picture of Ownership. Brussels: EFJ.

European Federation of Journalists. 2004. Eastern Empires. Foreign Ownership in Central and Eastern European Media: Ownership, Policy Issues and Strategies. Brussels: EFJ.

European Parliament. 2008. Resolution on Concentration and Pluralism in the Media in the European Union 2007/2253(INI). Brussels: European Parliament.

Farda, Constanze. 2000. Europäische Medienpolitik. Eine Policy-Analyse der Fernseh- und der Antikonzentrationsrichtlinie. Wiesbaden: Deutscher Universitäts-VErlag.

Federal Communications Commission (FCC). 2010. Media Ownership Rules Review. 2010 Media Ownership Studies. Washington, D. C. https://www.fcc.gov/general/2010-mediaownership-studies

Fuchs, Christian. 2009. Grundlagen der Kritik der Politischen Ökonomie der Medien. In Bruchstücke. Kritische Ansätze zu Politik und Ökonomie im globalisierten Kapitalismus, edited by Peter Fleissner and Natascha Wanek, 97-111. Berlin: trafo.

Fuchs, Christian and Vincent Mosco, eds. 2012. Marx is Back - The Importance of Marxist Theory and Research for Critical Communication Studies Today. tripleC: Communication, Capitalism \& Critique 10 (2) 127-632, http://www.triple-c.at/index.php/tripleC/article/view/427/400

Gabler Verlag, ed. 2012. Gabler Wirtschaftslexikon, Stichwort: wettbewerbspolitische Leitbilder. http://wirtschaftslexikon.gabler.de/Archiv/7590/wettbewerbspolitische-leitbilderv9.html

Hachmeister, Lutz and Günther Rager, eds. 2005. Wer beherrscht die Medien? Die 50 größten Medienkonzerne der Welt. Jahrbuch 2005. Munich: C. H. Beck.

Hans Bredow Institute, ed. 2009. Internationales Handbuch Medien. Baden-Baden: Nomos. $28^{\text {th }}$ edition.

Hans Bredow Institute. 2008. Zur Entwicklung der Medien in Deutschland zwischen 1998 und 2007. Wissenschaftliches Gutachten zum Kommunikations- und Medienreport (sic!) of the Federal Government (als Anlage zum Medien- und Kommunikationsbericht der Bundesregierung 2008). Hamburg. http://www.bundesregierung.de/Content/DE/ Anlagen/BKM/2009-01-12-medienberichtteil2-barrierefrei.pdf? blob=publicationFile\&v=3

Heinrich, Michael. 2005. Kritik der politischen Ökonomie. Eine Einführung. Stuttgart: Schmetterling. Third edition. 
Herman, Edward S. and Noam Chomsky. 2002. Manufacturing Consent. The Political Economy of the Mass Media. New York: Pantheon.

Herman, Edward S. and Robert McChesney. 1997. The Global Media. The New Missionaries of Corporate Capitalism. London/Washington: Bloomsbury Academic.

Holtz-Bacha, Christina. 2006. Von Dinosauriern, Haifischen und Heuschrecken. Zum Zustand des deutschen Zeitungsmarktes. Publizistik 51 (3): 287-289.

Holzer, Horst. 1994. Medienkommunikation. Einführung in handlungs- und gesellschaftstheoretische Konzeptionen. Opladen: Westdeutscher Verlag.

Huffschmid, Jörg. 2000. Zentralisierung und Monopolisierung des Kapitals - Aktuelle Tendenzen. In Geld ist genug da. Reichtum in Deutschland, edited by Herbert Schui and Eckart Spoo, 62-70. Heilbronn: Distel Verlag. Third edition.

Huffschmid, Jörg. 1992. Wettbewerb oder Wettbewerbsfähigkeit? Brisante Wandlung eines wirtschaftspolitischen Imperativs. In Politische Ökonomie im Wandel, edited by Andreas Schikora, Angela Fiedler and Eckhard Hein, 97-110. Marburg: Metropolis.

Huffschmid, Jörg. 1969. Die Politik des Kapitals. Konzentration und Wirtschaftspolitik in der Bundesrepublik. Frankfurt am Main: Suhrkamp.

Jin, Dal Yong. 2008. Neoliberal Restructuring of the Global Communication System: Mergers and Acquisitions. Media, Culture and Society 30 (3): 357-373.

Karppinen, Kari. 2010. Rethinking Media Pluralism. A Critique of Theories and Policy Discourses. Dissertation. Helsinki: University of Helsinki.

Karppinen, Kari. 2006. Media Diversity and the Politics of Criteria. Diversity Assessment and Technocratisation of European Media Policy. Nordicom Review 27 (2): 53-68.

Keiser, Günter. 1931. Die kapitalistische Konzentration. Beiträge zu ihrer Theorie und Begriffsbildung. Berlin: Struppe \& Winckler.

Kisker, Klaus Peter. 2000. Kapitalkonzentration und die Rolle des Staates im Zeitalter der Globalisierung, In Die Fusions-Welle. Die Großkapitale und ihre ökonomische Macht, edited by Joachim Bischoff, Paul Boccara, Karl Georg Zinn et al., 75-99. Hamburg: VSA.

Kisker, Klaus Peter. 1999. Kapitalkonzentration, Monopolisierung, Monopoltheorie - theoriegeschichtliche und aktuelle Aspekte. Zeitschrift Marxistische Erneuerung 39: 64-74.

Kleinsteuber, Hans J. 2003. Medien und Kommunikation im internationalen Vergleich: Konzepte, Methoden und Befunde. In Politische Kommunikation im internationalen Vergleich. Grundlagen, Anwendungen, Perspektiven, edited by Frank Esser and Barbara Pfetsch, 78-103. Wiesbaden: Westdeutscher Verlag.

Kleinsteuber, Hans J. and Barbara Thomaß. 2004. Medienökonomie, Medienkonzerne und Konzentrationskontrolle. In Medien und Ökonomie. Band 2: Problemfelder der Medienökonomie, edited by Klaus-Dieter Altmeppen and Matthias Karmasin, 123-158. Wiesbaden: VS Verlag für Sozialwissenschaften.

Knoche, Manfred. 2005a. Medienkonzentration als Macht- und Legitimationsproblem für Politik und Wissenschaft. Kritisch-empirische Konzentrationstheorie versus apologetisch-normative Wettbewerbstheorie. In Internationale partizipatorische Kommunikationspolitik. Strukturen und Visionen, edited by Petra Ahrweiler and Barbara Thomaß, 117-140. Münster/Hamburg/Berlin/London/Wien: Lit.

Knoche, Manfred. 2005b. Medienkonzentration und Meinungsvielfalt. Von empirischen Studien zur kapitalismuskritischen Medienkonzentrationstheorie. In Die Aktualität der Anfänge. 40 Jahre Publizistikwissenschaft an der Johannes Gutenberg-Universität Mainz, edited by Jürgen Wilke, 98-114. Cologne: Herbert von Halem Verlag.

Knoche, Manfred. 2005c. Medienökonomische Theorie und Ideologie im Kapitalismus. Einige zitatengestützte Überlegungen zu Marie Luise Kiefers »Medienökonomik« aus der Sicht einer Kritischen Politischen Ökonomie der Medien. In Bausteine einer Theorie des öffentlich-rechtlichen Rundfunks, edited by Christa-Maria Ridder, Wolfgang R. Langenbucher, Ulrich Saxer and Christian Steininger, 406-435. Wiesbaden: VS Verlag für Sozialwissenschaften.

Knoche, Manfred. 2004. Konkurrenz, Konzentration und Regulierung in der Medienindustrie, In Effiziente Medienregulierung. Marktdefizite oder Regulierungsdefizite?, edited by Mike Friedrichsen and Wolfgang Seufert, 157-171. Baden-Baden: Nomos. 
Knoche, Manfred. 2002. Kommunikationswissenschaftliche Medienökonomie als Kritik der Politischen Ökonomie der Medien. In Medienökonomie in der Kommunikationswissenschaft. Bedeutung, Grundfragen und Entwicklungsperspektiven, edited by Gabriele Siegert, 101-109. Münster/Hamburg/London: Lit.

Knoche, Manfred. 2001. Kapitalisierung der Medienindustrie aus politökonomischer Perspektive. Medien \& Kommunikationswissenschaft 49: 177-194.

Knoche, Manfred. 1997. Medienkonzentration und publizistische Vielfalt. Legitimationsgrenzen des privatwirtschaftlichen Mediensystems. In Kommunikationswelten. Wissenschaftliche Perspektiven zur Medien- und Informationsgesellschaft, edited by Rudi Renger and Gabriele Siegert, 123-158. Innsbruck/Vienna: Studien-Verlag.

Knoche, Manfred. 1996a. Konzentrationsboom und Forschungsdefizite. Von der Presse- zur Medienkonzentrationsforschung. In Ökonomie der Medien und des Mediensystems. Grundlagen, Ergebnisse und Perspektiven medienökonomischer Forschung, edited by Klaus-Dieter Altmeppen, 101-120. Wiesbaden: Westdeutscher Verlag.

Knoche, Manfred. 1996b. Konzentrationsförderung statt Konzentrationskontrolle. Die Konkordanz von Medienpolitik und Medienwirtschaft. In Markt - Macht - Medien. Publizistik im Spannungsfeld zwischen gesellschaftlicher Verantwortung und ökonomischen Zielen, edited by Claudia Mast, 105-117. Konstanz: UVK.

Knoche, Manfred. 1978. Einführung in die Pressekonzentrationsforschung. Theoretische und empirische Grundlagen - Kommunikationspolitische Voraussetzungen. Berlin: Spiess.

Knoche, Manfred and Axel Zerdick. 2002. Vergleich der kartellrechtlichen Regelungen und ihrer Rechtsanwendung für Fusionen und Kooperationen im Bereich Presse und Presswerßhandel in Europa und den USA. Unpublished research report for the Federal Ministry of Economics and Technology (Bundesministerium für Wirtschaft und Technologie, Germany). Salzburg/Berlin.

Kommission zur Ermittlung der Konzentration im Medienbereich (KEK), ed. 2010. Auf dem Weg zu einer medienübergreifenden Vielfaltsicherung. (Vierter Konzentrationsbericht). Berlin.

Kommission zur Ermittlung der Konzentration im Medienbereich (KEK), ed. 2007. Crossmediale Verflechtungen als Herausforderung für die Konzentrationskontrolle. (Dritter Konzentrationsbericht). Berlin.

Kopper, Gerd G. 1995. New Method of Concentration Research. In Media Structure and the State. Concepts, Issues and Measures, edited by Karl Erik Gustafsson, 96-113. Gothenburg: Gothenburg University.

Kroes, Neelie. 2012. Safeguarding Media Pluralism in the EU. "United in Diversity" Pan-European Forum on Media Pluralism \& New Media. Brussels: European Parliament. http://ec.europa.eu/information society/newsroom/cf//itemdetail.cfm?item id=8240

Leidinger, Christiane. 2003. Medien - Herrschaft - Globalisierung. Folgenabschätzung zu Medieninhalten im Zuge transnationaler Konzentrationsprozesse. Münster: Westfälisches Dampfboot.

Luyken, Georg-Michael.1990. Das Medienwirtschaftsgefüge der 90er Jahre. Horizontale und vertikale Unternehmensverflechtungen - Neue strategische Allianzen - Öffentliches Interesse. In Media Perspektiven 10: 621-641.

Mandel, Ernest. 1978. Late Capitalism. London: Verso.

Marx, Karl. 1867. Capital Volume I. London: Penguin.

McChesney, Robert W. 2000. The Political Economy of Communication and the Future of the Field. Media, Culture \& Society 22 (1): 109-116.

McChesney, Robert W. 2008. The Political Economy of Media. Enduring Issues, Emerging Dilemmas. New York: Monthly Review Press.

McChesney, Robert W. and John Nichols. 2004. Unsere Medien? Demokratie und Medienkonzerne in den USA. Berlin: Verlag Schwarzer Freitag.

McChesney, Robert W., Ellen Meiksins Wood, and John Bellamy Foster, eds. 1998. Capitalism and the Information Age. The Political Economy of the Global Commucation Revolution. New York: Monthly Review Press. 
Media Diversity Institute, International Federation of Journalists, and Internews Europe. 2009. Media4Diversity. Taking the Pulse of Diversity in the Media. A Study on Media and Diversity in EU Member States and 3 EEA Countries. Study for the European Commission. Luxembourg. https://ec.europa.eu/social/main.jsp?langld=en\&catld=89\&newsld $=512$

Meier, Werner A. 2007. National and Transnational Media Ownership Concentration in Europe: A Burden for Democracy? In Power, Performance and Politics. Media Policy in Europe, edited by Werner A. Meier and Josef Trappel, 75-104. Baden-Baden: Nomos.

Meier, Werner A. 2003. Politische Ökonomie. In Medien und Ökonomie. Band 1/1: Grundlagen der Medienökonomie: Kommunikations- und Medienwissenschaft, Wirtschaftswissenschaft, edited by Klaus-Dieter Altmeppen and Matthias Karmasin, 215-243. Wiesbaden: VS Verlag für Sozialwissenschaften.

Meier, Werner A. 1996/1997. Globaler Medienwandel aus politökonomischer Perspektive. Medienwissenschaft Schweiz 2 (1996) \& und 1 (1997): 70-85.

Melischek, Gabriele, Josef Seethaler, and Jürgen Wilke, eds. 2008. Medien \& Kommunikationsforschung im Vergleich: Grundlagen, Gegenstandsbereiche, Verfahrensweisen. Wiesbaden: VS Verlag für Sozialwissenschaften.

Mosco, Vincent. 2009. The Political Economy of Communication. London: Sage. Second edition.

Murdock, Graham. 1990. Redrawing the Map of the Communications Industries: Concentration and Ownership in the Era of Privatization. In Public Communication. The New Imperatives. Future Directions for Media Research, edited by Marjorie Ferguson, 1-15. London: Sage.

Murdock, Graham and Peter Golding. 1973. For a Political Economy of Mass Communication. The Socialist Register 10: 205-234.

Noam, Eli M. 2009. Media Ownership and Concentration in America. Oxford: Oxford University Press.

Nordicom. 2009. The Nordic Media Market. Media Companies and Business Activities. Compiled by Eva Harrie. Second edition. Göteborg: Nordicom.

Ofcom (Office of Communications UK). 2012. Communications Market Report 2012. London: Ofcom. http://stakeholders.ofcom.org.uk/binaries/research/cmr/cmr12/CMR UK 2012.pdf

Olten, Rainer. 1998. Wettbewerbstheorie und Wettbewerbspolitik. München/Wien: R. Oldenbourg Verlag. Second edition.

Prokop, Dieter. 2005. Der kulturindustrielle Machtkomplex. Neue kritische Kommunikationsforschung über Medien, Werbung und Politik. Cologne: Herbert von Halem Verlag.

Rittner, Fritz and Michael Kulka. 2008. Wettbewerbs- und Kartellrecht. Eine systematische Darstellung des deutschen und europäischen Rechts für Studium und Praxis. Heidelberg: Müller. Seventh edition.

Röper, Horst. 2012. Zeitungsmarkt 2012: Konzentration erreicht Höchstwert. Daten zur Konzentration der Tagespresse in der Bundesrepublik Deutschland im 1. Quartal 2012. In Media Perspektiven 5 (2012): 268-285.

Sánchez-Tabernero, Alfonso and Miguel Carvajal. 2002. Media Concentration in the European Market. New Trends and Challenges. Pamplona: University of Navarra.

Schmidt, Ingo. 2012. Wettbewerbspolitik und Kartellrecht. Eine interdisziplinäre Einführung. Stuttgart: Gustav Fischer Verlag. Ninth edition.

Schneider, Beate and Walter Schütz, eds. 2004. Europäische Pressemärkte. Annäherungen an eine länderübergreifende Zeitungsstatistik. Wien: Verlag der Österreichischen Akademie der Wissenschaften.

Schulz, Wolfgang and Thorsten Held. 2006. Die Zukunft der Kontrolle der Meinungsmacht. Gutachten für die Friedrich-Ebert-Stiftung. Berlin: Friedrich-Ebert-Stitung.

Schulz, Wolfgang, Thorsten Held, and Sascha Arnold. 2007. Regulierung crossmedialer Aktivitäten in ausländischen Medienordnungen. Arbeitspapiere des Hans-Bredow-Instituts Nr. 18. Hamburg: Hans-Bredow-Institut. 
Schulz, Wolfgang, Stephan Dreyer, and Stefanie Hagemeier. 2011. Machtverschiebung in der öffentlichen Kommunikation. Bonn: Friedrich-Ebert-Stitung.

Seethaler, Josef. 2004. Vergleichende Ansätze in der Erforschung der europäischen Pressemärkte: Ein Literaturbericht. In Europäische Pressemärkte. Annäherungen an eine länderübergreifende Zeitungsstatistik, edited by Beate Schneider and Walter Schütz, 129-163. Wien: Verlag der Österrichischen Akademie der Wissenschaften.

Seethaler, Josef and Gabriele Melischek. 2006. Die Pressekonzentration in Österreich im europäischen Vergleich. Österreichische Zeitschrift für Politikwissenschaft 35 (4): 337-360.

Siegert, Gabriele, Werner A. Meier, and Josef Trappel. 2010. Auswirkungen der Ökonomisierung auf Medien und Inhalte. In Einführung in die Publizistikwissenschaft, edited by Heinz Bonfadelli, Otfried Jarren and Gabriele Siegert, 517-542. Bern: Haupt Verlag. Third edition.

Sjurts, Insa. 2005. Strategien in der Medienbranche: Grundlagen und Fallbeispiele. Wiesbaden: Gabler. Third edition.

Stürzebecher, Dieter. 2004. Europäische Pressemärkte - Grundlagen und Statistik des Zeitungswesens, In Europäische Pressemärkte. Annäherungen an eine länderübergreifende Zeitungsstatistik, edited by Beate Schneider and Walter Schütz, 95-112. Wien: Verlag der Österrichischen Akademie der Wissenschaften.

Sweezy, Paul M. 1970. The Theory of Capitalist Development. Principles of Marxian Political Economy. New York: Monthly Review Press.

Thomaß, Barbara and Hans J. Kleinsteuber. 2011. Comparing Media Systems: The European Dimension. In Media in Europe Today, edited by Josef Trappel, Werner A. Meier, Leen d'Haenens, Jeanette Steemers, and Barbara Thomaß, 23-41. Bristol: Intellect.

Thomaß, Barbara and Michaela Tzankoff, eds. 2001. Medien und Transformation in Osteuropa. Wiesbaden: Westdeutscher Verlag.

Trappel, Josef, Werner A. Meier, Leen d'Haenens, Jeanette Steemers, and Barabra Thomaß, eds. 2011. Media in Europe Today. Bristol: Intellect.

Trappel, Josef, Werner A. Meier, Klaus Schrape, and Michaela Wölk. 2002. Die gesellschaftlichen Folgen der Medienkonzentration. Veränderungen in den demokratischen und kulturellen Grundlagen der Gesellschaft. Opladen: Leske + Budrich.

Vogel, Andreas. 2012. Publikumszeitschriften 2012: Kaum Anteilsverschiebungen im rückläufigen Markt. Daten zum Markt und zur Konzentration der Publikumspresse in Deutschland im 1. Quartal 2012. Media Perspektiven 6 (2012): 317-398.

Wasko, Janet, Graham Murdock, and Helena Sousa, eds. 2011. The Handbook of Political Economy of Communications. Chichester: Wiley.

Wilke, Jürgen, ed. 1992/1994/1996. Massenmedien in Lateinamerika. Band 1-3. Frankfurt: Vervuert.

Winseck, Dwayne and Dal Yong Jin, eds. 2011. The Political Economies of Media. The Transformation of the Global Media Industries. London/New York: Bloomsbury Academic.

\section{About the Author}

Manfred Knoche is professor emeritus of media economics at the University of Salzburg in Austria. He studied journalism, sociology, political science and economics at the University of Mainz and the Free University of Berlin. He obtained his PhD (1978) and defended his habilitation (1981) at the Free University of Berlin. He was research assistant in the years 19741979 and assistant professor for communications politics in Berlin in the years 1979-1983. From 1983-1994, he was professor of media and communication studies at the Vrije Universiteit Brussel in Belgium, where he was also the director of the Centre for Mass Communications Research. From 1994-2009 he held the chair professorship for journalism and communication studies with special focus on media economics at the Institute for journalism and communication studies at the University of Salzburg in Austria, where he was the head of the department for media economics and empirical communication research. He chaired the German Association for Media and Communication Studies' (DGPuK) media economics-section. He is author 
of many publications on the critique of the political economy of the media. His work has especially focused on the critique of the political economy of media concentration and the media industry's structural transformations.

http://www.medienoekonomie.at, https://kowi.uni-salzburg.at/ma/knoche-manfred/

Twitter: @Medoek

Wikipedia: https://de.wikipedia.org/wiki/Manfred Knoche 